\title{
Pemanfaatan Sumber Bacaan Berbasis Augmented Reality Untuk Gerakan Literasi Di Sekolah Dasar
}

\author{
${ }^{1}$ Heri Setiawan, ${ }^{2}$ Styo M. W. Aji, ${ }^{3}$ Itsna Oktaviyanti, ${ }^{4}$ Ilham S. Jiwandono, ${ }^{5}$ Awal \\ N.K Rosyidah, ${ }^{6}$ Ida Bagus Kade Gunayasa \\ 1, 3, 4, 5, 6 PGSD FKIP Universitas Mataram, Indonesia \\ ${ }^{2}$ Mahasiswa PPG Pascasarjana Universitas Negeri Malang, Indonesia \\ Email: ${ }^{1}$ heri_setiawan@unram.ac.id, ${ }^{2}$ \\ styo.mahendra.1621038@ students.um.ac.id, ${ }^{3}$ itsna@unram.ac.id, \\ ${ }^{4}$ Ilham_jiwandono@unram.ac.id
}

\begin{tabular}{l}
\hline Tersedia Online di \\
\hline http://www.jurnal.unublitar.ac.id/i \\
ndex.php/briliant \\
\hline Sejarah Artikel \\
\hline Diterima pada 24 September 2020 \\
Disetujui pada 8 Februari 2021 \\
Dipublikasikan pada 28 Februari \\
2021 \\
Hal. 146-156 \\
\hline
\end{tabular}

Kata Kunci:

Sumber bacaan; Augmented

Reality; Gerakan Literasi

\section{DOI:}

http://dx.doi.org/10.28926/briliant.

v3i4.554

\begin{abstract}
Abstrak: Kajian ini bertujuan untuk menganalisis potensi pemanfaatan sumber bacaan berbasis augmented reality untuk gerakan literasi di sekolah dasar. Metode yang digunakan yaitu melakukan kajian literature (literature review) dengan menganalisis tentang gerakan literasi di sekolah dasar, literasi dan teknologi, dan sumber bacaan augmented reality. Berdasarkan analisis dihasilkan gambaran langkah-langkah yang dapat digunakan untuk memanfaatkan sumber bacaan berbasis augmented reality yaitu melalui: (1) mempersiapkan bahan bacaan; (2) memilih bahan bacaan; (3) menginstal aplikasi untuk buku berbasis augmented reality pada gawai; (4) kegiatan membaca; dan (5) kegiatan diskusi. Pemanfaatan ini diharapkan dapat mendorong siswa semakin memiliki gairah berliterasi.
\end{abstract}

\section{PENDAHULUAN}

Literasi termasuk isu mutakhir yang dibahas dalam dunia pendidikan. Hal ini dikarenakan kedudukan literasi yang merupakan bagian integral dalam dunia pendidikan. Kedudukan strategis ini tentunya memberikan konsekuensi kepada pelaksanaan literasi di sekolah-sekolah.

Keterkaitan literasi dengan kehidupan di sekolah dapat dilihat dari makna literasi itu sendiri. Pada artian sederhana literasi dipahami sebagai "kepemahaman" atau "kemelekan". Makna lebih jauh kemelakan diartikan sebagai kemelekan "baca" dan "tulis". Inilah yang menjadikan literasi memeliki peranan dalam pelaksanaan pembelajaran di sekolah. Kedua kemampuan dasar ini menjadi jalan untuk memahami atau melek, dan memecahkan masalah berbagai hal dalam pembelajaran di sekolah maupun hal lain.

Terdapat alasan kuat pemerintah sedang menggalakan literasi di sekolah. Hasil asesmen internasional yang dilakukan oleh OECD menggambarkan kondisi 
literasi di berbagai negara. Asesmen ini bernama Programme for International Student Assessment (PISA). Literasi dalam asesmen PISA mencakup literasi membaca (reading literacy), literasi matematika (mathematical literacy), dan literasi sains (scientific literacy).

Data hasil asesmen yang dilaksanakan 2018 menunjukkan rendahnya literasi siswa Indonesia. Rata-rata skor perolehan literasi membaca siswa Indonesia yaitu 371. Sementara pada literasi matematika skor yang diperoleh mencapai 379. Terakhir pada literasi sains skor yang dicapai yaitu 396. Skor-skor yang diperoleh ini mengantarkan siswa Indonesia menduduki peringkat 74 dari 79 negara yang berpartisipasi (OECD, 2018).

Skor yang diperoleh pada tahun 2018 ini menurun dibandingkan dengan perolehan skor asesmen yang dilaksanakan sebelumnya. Pada asesmen 2015 skor yang diperoleh siswa Indonesia menapai 397 untuk literasi membaca, 386 untuk literasi matematika dan 403 untuk literasi sains. Hal yang perlu diperhatikan lagi adalah skor asesmen yang diperoleh pada tahun 2018 ini masih dibawah rata-rata perolehan skor keseluruhan negara-negara partisipan PISA 2018. Rata-rata skor pada tahun 2018 yaitu 487 untuk literasi membaca, 489 untuk literasi matematika dan 489 untuk literasi sains.

Perolehan hasil ini seyogyanya menjadi peringatan dan bahan kajian tersendiri untuk mempersiapkan generasi Indonesia kedepannya. Hasil yang rendah ini dikhawatirkan menghasilkan sumber daya manusia Indonesia yang kurang kompetitif, ditengah persaingan manusia yang mulai mengglobal ini. Rendahnya kualitas sumber daya manusia sebagai dampak dari rendahnya minat untuk literasi baca dan tulis (Setiawan et al, 2019). Membaca dan menulis belum menjadi kebutuhan utama bagi siswa Indonesia. Meskipun para siswa mengetahui bahwa membaca dan menulis merupakan pintu dari pengetahuan dan pemecahan masalah.

Pemerintah Indonesia telah berupaya untuk memperhatikan literasi menjadi prioritas untuk membangun manusia Indonesia secara berkesinambungan. Pada tahun 2016 pemerintah mengeluarkan kebijakan gerakan literasi sekolah. Besar harapan pemerintah terhadap program ini. Gerakan literasi diharapkan dapat melahirkan manusia Indonesia yang berkarakter sehingga dapat bersaing dalam persaingan yang global ini. Oleh karena itu, perlu ada kerjasama dan keterlibatan yang baik antar seluruh stakeholder pelaksana gerakan literasi.

Tentu Guru merupakan tokoh utama dalam pelaksanaan gerakan literasi. Literasi bukan hanya sekedar dilaksanakan. Literasi membutuhkan penyediaan bahan bacaan yang dapat menarik dan bervariasi bagi siswa untuk berliterasi. Oleh karena itu, perlu adanya penyediaan bahan untuk literasi yang menarik, kreatif ataupun inovatif.

Salah satu alternatif sumber bacaan yang dapat diggunakan oleh guru yaitu sumber bacaan berbasis Augmented Reality. Azuma (1997) mendefiniskan Augmented Reality sebagai sebuah teknologi yang menggabungkan antara dunia nyata dengan dunia maya, bersifat interaktif sesuai dengan waktu nyata (real time), serta berbentuk animasi tiga dimensi. Augmented Reality juga dapat didefinisikan sebagai teknologi yang menggabungkan benda maya dua dimensi atau tiga dimensi untuk kemudian memproyeksikan benda maya tersebut dalam bentuk nyata (Valino, 1996). Sehingga, befrdasar dua definisi tersebut Augmented Reality (AR) 
dapat didefinisikan sebagai sebuah teknologi yang mampu menggabungkan antara benda maya dalam wujud dua dimensi maaupun tiga dimensi dalam sebuah lingkungan nyata kemudian diproyeksikan atau ditampilkan secara real time.

Augmented Reality merupakan sebuah konsep menggabungkan dunia maya dengan dunia nyata guna menghasilkan informasi dari data yang diambil dari sebuah sistem pada objek nyata yang ditunjuk sehingga batas antara keduanya menjadi semakin tipis (Mustaqim, 2016). Dalam pemanfaatannya, Augmented Reality dapat menciptakan interaksi antara dunia nyata dengan dunia maya. Semua informasi dapat ditambahkan sehingga informasi tersebut ditampilkan secara real time seolah-olah informasi tersebut menjadi interaktif dan nyata. Tentu akan menjadi sebuah hal yang menarik pembaca jika teknologi Augmented Reality ini dimanfaatkan sebagai sumber bacaan karena pembaca dapat diajak secara real time menyaksikan dan merasakan secara nyata objek yang dibacanya.

Literasi pada era ini idealnya menggunakan teknologi terkini yang sesuai dengan perkembangan siswa. Penggunaan teknologi membuka peluang ketersediaan sumber bacaan litersi yang lebih beragam dan sesuai dengan karakteristik siswa pada era ini. Hal inilah yang mendorong penulis untuk mengangkat judul "Pemanfaatan Sumber Bacaan Berbasis Augmented Reality untuk Gerakan Literasi di Sekolah Dasar."

\section{METODE}

Artikel ini menggunakan metode kajian pustaka (literature review). Beragam literature yang menyangkut tentang sumber bacaan berbasis augmented reality dan gerakan literasi sekolah dasar (Setiawan et al, 2019; Setiawan et al, 2020). Pengkajian dilakssanakan dengan langkah utama yaitu pencarian sumber kajian baik dai buku, artikel dalam jurnal, dan sumber lain yang relevan. Dari berbagai sumber tersebut dilakukan analisis dan pengkajian guna merumuskan topik utama yaitu peemanfaatan augmented reality dalam penguatan literasi, yaitu sebagai sumber bacaan ssiwa di sekolah dasar. Prosedur ini digunakan untuk mengkaji peluang pemanfaatan sumber bacaan berbasis augmented reality untuk pelaksanaan gerakan literasi di sekolah dasar.

\section{PEMBAHASAN}

\section{Kajian Pelaksanaan Gerakan Literasi Sekolah}

Pelaksanaan gerakan literasi sekolah telah dilaksanakan sejak 2016. Pelaksanaan gerakan ini diharapkan dapat membentuk manusia Indonesia yang literat. Apabila dilaksanakan dengan baik, tentu pelaksanaan gerakan literasi ini dapat memberikan kontribusi untuk membangun sumber daya manusia Indonesia yang literat kedepannya. Manusia literat yang berarti memiliki kapabilitas untuk mencari, memahami, dan menggunakan informasi secara cerdas untuk kehidupannya melalui keterampilan membaca, menyimak, menulis, dan berbicara (Kemendikbud, 2016). Pelaksanaan gerakan literasi sekolah ini dipandu dengan instrumen untuk melaksanakan sesuai dengan prosedur yang ada.

Pelaksanaan gerakan literasi yang sudah berjalan bertahun-tahun sejak digalakan pada tahun 2016. Namun, hingga saat ini pemerintah belum merilis pasti data tentang keterlaksanaan, hasil, dan dampak dari pelaksaan gerakan literasi 
sekolah secara resmi. Data hasil literasi sangat dibutuhkan untuk mengembangkan gerakan literasi di sekolah-sekolah itu sendiri. Mengingat setiap sekolah memiliki tantangan yang berbeda untuk melaksanakannya. Sungguh tidak adil apabila pemerintah menggalakan sebuah program, namun tidak ada evaluasi untuk perbaikan.

Evaluasi secara internasional tentang literasi yang dirilis oleh OECD melalui PISA bertahun-tahun telah menunjukkan posisi Indonesia di peringkat bawah. Hal ini selayaknya menjadi dorongan pemerintah untuk melakukan evaluasi tentang gerakan literasi sekolah secara mandiri. Keberagaman di Indonesia merupakan sebuah kekayaan sekaligus tantangan pemerintah untuk meninjau pelaksanaan gerakan literasi. Setiap sekolah memiliki tantangan-tantangan sendiri dalam pelaksanaanya. Selain tantangan, ada juga sekolah yang memiliki potensi untuk mengembangkan gerakan literasi sekolah. Potensi-potensi inilah yang selanjutnya dapat menjadi model bagi sekolah lain. Oleh karena itu, setiap sekolah dapat saling belajar, dan kedepannya ada perbaikan terhadap literasi berkelanjutan. Lebih jauh, tentunya dampak yang diharapkan adanya peningkatan dalam edisiedisi evaluasi PISA selanjutnya.

Pelaksanaan literasi sekolah yang telah berjalan sangat disayangkan belum dievaluasi oleh pemerintah hingga hari ini. Namun,kita masih bisa berharap untuk dapat melihat kondisi pelaksanaan gerakan literasi sekolah dari hasil penelitianpenelitian dalam rumpun literasi sekolah. Setiap sekolah memiliki kondisi berbedabeda. Dari hasil penelitian ini diharapkan ada gambaran real dari pelaksanaan gerakan literasi sekolah.

Penelitian dari Khotimah, dkk. (2018) menemukan pelaksanaan literasi sekolah di salah satu SD di Kota Malang belum dilaksanakan sepenuhnya secara baik. Beberapa masalah dihadapi berdasarkan penelitian ini. Panduan yang telah dirilis belum digunakan sebagai pedoman melaksanakan gerakan literasi sekolah. Tahapan-tahapan pada panduan belum dilaksanakan. Perpustakaan sekolah yang telah memiliki koleksi buku bacaan mencapai ribuanpun belum dijadikan sebagai pusat sumber pengatahuan, dan sumber belajar bagi siswa sepenuhnya. Potensi bahan bacaan yang bervariasi ini idealnya menjadi potensi sebagai pendukung pelaksanaan gerakan literasi sekolah. Sarana pendukung ini dapat memberikan sumbangan peningkatan literasi bagi siswa dan strategi pelaksnaannya.

Sementara itu, temuan serupa juga ditemukan hasil penelitian dari Hidayat, dkk. (2018). Penelitian ini dilakukan di dua lokasi. Di sekolah pertama pelaksanaan literasi mengalami hambatan. Hambatan yang ditemukan yaitu koleksi sumber bacaan yang masih kurang, belum adanya ruangan khusus untuk perpustakaan, di kelas rendah belum ada literasi, dan belum adanya dukungan khusus baik dari orang tua maupun pemerintah mengenai literasi. Sementara itu, temuan di lokasi sekolah kedua juga ditemukan beberapa hambatan. Pelaksanaan literasi terhambat oleh rendahnya minat baca siswa, tingkatan kegiatan masih stagnan belum meningkat, belum fokusnya guru untuk membina kegiatan literasi, dan kurangnya pembinaan dari pemerintah dalam pelaksanaan gerakan literasi.

Berdasarkan temuan penelitian-penelitian ini dapat ditarik beberapa garis besar tentang pelaksanaan gerakan literasi selama ini. Gerakan literasi belum sepenuhnya dilaksanakan dengan baik. Bahan bacaan bagi siswa yang beragam 
belum tentu dimanfaatkan, sehigga belum meningkatkan minat baca anak. Variasi kegiatan menjadi tantangan bagi guru. Kegiatan membaca sumber bacaan literasi sejenis secara berulang membuat pelaksanaan gerakan literasi belum meningkat. Oleh karena itu, perlu adanya strategi-strategi alternatif untuk mengembangkan literasi di sekolah dasar ini.

\section{Literasi dan Teknologi}

Perkembangan siswa sekolah dasar yang ada kini jauh lebih akrab dengan gawai dibandingkan dengan generasi-generasi siswa sekolah dasar sebelumnya. Pada masa ini anak yang menjadi siswa sekolah dasar merupakan generasi Alpha. Generasi ini lahir setelah generasi X,Y, dan Z. Tokoh McCrindle menyatakan bahwa generasi Alpha merupakan generasi yang lahir setelah tahun 2010 (dalam Sterbenz, 2015).

Generasi Alpha memiliki karaksteristik khas dibandingkan generasi sebelumnya. Generasi Alpha lahir pada saat teknologi sudah berkembang pesat. Mereka bukan lagi menjadi migran dalam teknologi seperti generasi sebelumnya. Generasi alpha sangatlah akrab dengan teknologi sejak lahir. Selanjutnya generasi ini memliki karakter yang khas. Anak yang termasuk generasi Alpha menurut Tootel, etc (2014) memiliki karakter: (1) merupakan pribumi digital, (2) akrab dengan teknologi yang telah menjadi kehidupan sehari-hari dipengaruhi oleh interaksi sosialnya, (3) penutur asli dari bahasa digital melalui gawai, internet, game, dan internet yang memiliki keterampilan dalam hal teknologi lebuh baik apabila dibandingkan dengan gernerasi yang lahir sebelum-sebelumnya.

Lahirnya generasi Alpha yang kini mulai menginjak menjadi siswa sekolah dasar merupakan tantangan bagi pelaksanaan gerakan literasi sekolah di Indonesia. Pemangku kepentingan di sekolah dasar perlu mempersiapkan alternatif strategi bagi siswa yang sejak lahir telah mengenal teknologi ini. Literasi tidak lagi dibatasi kepada kemelekan siswa terhadap bacaan yang tekstual. Disamping itu juga kemelekan terhadap sumber bacaan yang berjenis digital.

Setidaknya ada dua hal yang perlu diperhatikan guru sebagai strategi dalam pelaksanaan gerakan literasi untuk siswa generasi alpha. Pertama, bacaan yang berjenis digital. Sumber bacaan berjenis digital pada era ini berkembang secara cepat. Sebelum sumber bacaan dalam bentuk tekstual ada dipasaran, bacaan yang berjenis digital mungkin telah beredar dipasaran terlebih dahulu. Apabila guru dapat mengakrabkan siswa dengan sumber bacaan digital, maka penyerapan informasi dapat dilakukan oleh siswa secara cepat, atau dengan kata lain lebih efisien dari segi waktu dan biaya. Siswa tidak perlu menunggu waktu hingga buku cetak beredar dipasaran. Sementara dari segi biaya, harga buku digital harganya hampir separuh dari harga buku cetak. Pelaksanaan gerakan literasi juga diuntungkan dengan adanya variasi sumber bacaan digital. Siswa tidak sekedar membaca buku teks itu-itu saja. Kedua, penggunaan teknologi. Sebagai generasi yang sejak lahir arab dengan teknologi pada gawai. Siswa-siswa generasi alpha tidak bisa hidup jauh-jauh dari gawai. Penggunaan gawai dapat mendorong pelaksanaan literasi agar lebih bervariasi. Siswa dapat memperoleh informasi yang bermafaat bagi dirinya menggunakan teknologi yang ada dalam gawai.

Literasi dan teknologi berjalan berdampingan. Kemelakan informasi menjadi kebutuhan para siswa untuk menjadi literat. Sementara kemelekan 
teknologi mengantarkan siswa menggunakan teknologi secara bijak. Teknologi digunakan untuk memperoleh informasi yang sekiranya bermanfaat dan membuat siswa berkembang.

Penggunaan gawai cerdas seperi, tablet pcl smartphone/ telepon seluler pintar semakin tidak bisa dijauhkan bagi siswa generasi alpha. Fenomena ini dapat menjadi kajian menarik bagi dunia pembudayaan literasi sekolah. Gawai-gawai ini, apabila digunakan dengan tepat memiliki beragam potensi untuk membantu melaksanakan pembiasaan literasi. Smartphone memiliki bergam fitur yang dapat digunakan sebagai alat bantu mengefektikan literasi sebagai media. Dua fitur yang sejauh ini dinilai dapat membantu literasi siswa-siswa generasi milenial khususnya alpha yaitu VR (virtual Reality) dan AR (Augmented Reality). Kedua fitur ini berpotensi membantu siswa untuk menjadi media antara dunia virtual dan nyata.

\section{Bahan Bacaan Berbasis Augmented Realility}

Seiring berkembangnya teknologi, pengemasan bahan bacaan yang dimanfaatkan bagi siswapun semakin beragam. Buku sebagai bahan bacaan tidak hanya tekstual saja. Buku kini dikemas semakin menarik. Buku yang selama ini dikemas dengan tulisan dan ilustrasi didalamnya kini semakin berkembang berkat adanya teknologi dari smartphone.

Teknologi pada smartphone memberi kesempatan isi buku tidak selalu tehenti pada tulisan dan ilustrasi gambar dua dimensi tekstual. Melalui teknologi ini, siswa berkesampatan mendapatkan ilustrasi tiga dimensi dari bahan bacaan. Teknologi yang digunakan ini bernama AR (augmented reality). Augmented reality menurut Kesim dan Ozarlan (2012) sebuah teknologi yang memadukan obyek dunia nyata dengan dunia virtual. Pada augmented reality ini sebuah obyek yang mungkin sulit dihadirkan secara nyata dapat dibantu kehadirannya secara virtual. Oleh sebab itu, obyek-obyek yang ada di dalam buku bacaan siswa yang dua dimensi dapat dihadirkan tiga dimensi secara virtual di gawai. Setidaknya ada tiga ciri yang dapat menggambarkan teknologi augmented reality, yaitu: mengkombinasikan nyata dengan virtual, adanya interaksi pada waktu sebenarnya dengan pengguna, dan adanya obyek 3 dimensi (Azuma, 1997).

Melalui teknologi augmented reality siswa dapat melihat animasi tokoh, obyek, ataupun lainnya yang berkaitan, dengan dibantu aplikasi-aplikasi milik buku pada smartphone dan tablet. Adanya animasi ini membantu memvisualkan atau melihat gambaran tiga dimensi yang lebih nyata lagi bagi siswa isi buku yang terkandung. Kini buku-buku bacaan dengan teknologi augmented reality ini banyak yang tersedia bagi anak usia sekolah dasar. Berikut ini contoh gambara buku dengan teknologi augmented reality. 


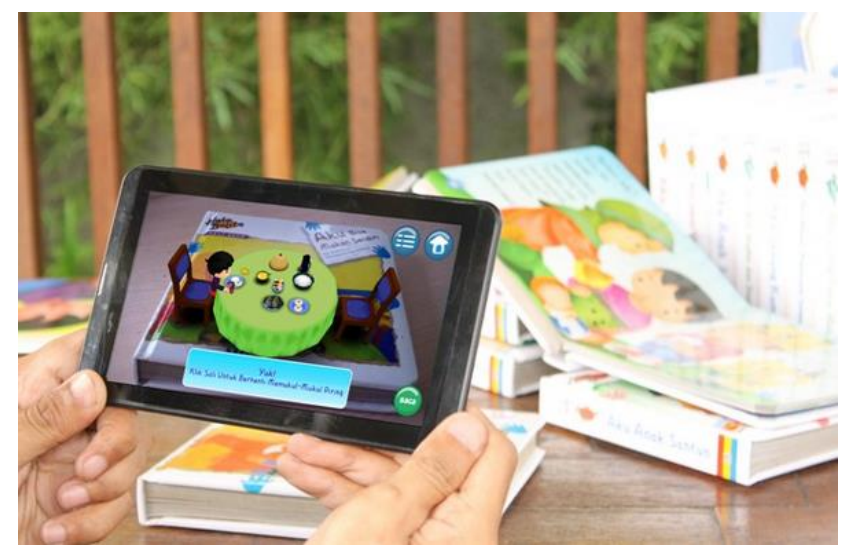

Gambar 1.Buku berbasis Augmented Reality

(Sumber: mizanapps.com/augmented-reality)

Berdasarkan gambar 1, buku augmented reality semakin berpotensi membantu siswa memvisualkan sesuatu yang abstrak pada teks. Bahan bacaan berbasis augmented reality dapat memvisualisasikan konsep abstrak untuk pemahaman dan struktur suatu model objek memungkinkan augmented reality sebagai media baca yang lebih efektif (Mustaqim, 2016). Gambar akan membantu siswa sekolah dasar lebih mengkongkretkan sesuatu yang abstrak. Jika demikian, maka buku bacaan berbasis augmented reality sesuai dengan tingkat perkembangan siswa sekolah dasar. Apabila ditinjau menurut teori perkembangan dari Piaget, siswa sekolah dasar berada pada tahap perkembangan praoperasional kongkrit hingga operasional kongkrit (Dahar, 2013). Pada prinsinya siswa pada tahap perkembangan kognitif rentangan usia sekolah dasar membutuhkan media-media yang akan membantu berpikir logis/ abstrak.

Teknologi augmented reality membuka peluang siswa untuk mendapatkan pengalaman literasi yang berbeda dari sebelumnya. Pembiasaan literasi akan lebih interaktif dan menarik. Pengalaman ini membuat pembiasaan literasi berpeluang lebih menarik. Faktor kemenarikan dalam dunia pendidikan sangatlah penting. Menurut Degeng (2013) kemenarikan dapat memberikan penghargaan dan keinginan lebih oleh siswa. Artinya, dengan digunakannya buku bacaan berbasis augmented reality, siswa berpeluang lebih tertarik untuk membaca yang disertai pengalaman visual tiga dimensi. Kemudian dampak lanjutan yang diperoleh yaitu keinginanan lebih oleh siswa untuk tetap berliterasi karena betah.

Teknologi AR dapat membantu dalam proses belajar mengajar dalam pengembangan literasi dan pendidikan di sekolah dasar. Teknologi AR memang tidak dapat menggantikan peran manusia dalam hal ini guru maupun orang tua, namun teknologi ini dapat membantu dan memperudah siswa untuk memaksimalkan pengetahuan yang diperoleh dari sumber bacaan berbasis AR. Menampilkan visual, audio, dan video dalam suatu media dalam hal ini bahan bacaan berbasis AR akan meningkatkan efektifitas dalam kegiata literasi baca siswa (Suryaningsih. A, 2019).

Selain itu, AR memiliki kelebihan karena sifatnya yang mampu mewujudkan benda bik duaa dimensi mapun tiga dimensi secara nyata. Tentu akan menjadi sebuah nilai tambah tersendiri karena siswa tidak hanya membaca dan 
berimajinasi, namun juga seolah-oleh merasakan dan mengalami langsung topik yang dibaca. Tentu pengalaman ini juga dapat mengkonkritkan konsep atau suatu materi yang menjadi topik bacaan siswa. Hal ini sesuai dengan pendapat Mustaqim (2016) yaitu pemanfaatan augmented reality dapat meningkatkan proses belajar serta minat peserta didik dalam belajar karena dalam augmented reality sendiri memiliki aspek-aspek hiburan yang dapat meningkatkan minat peserta didik dalam belajar dan bermain serta memproyeksikannya secara nyata dan melibatkan interaksi seluruh panca indera peserta didik dengan teknologi augmented reality ini.

Kelebihan dari augmented reality ebagai media bacaan maupun media pembelajaran dipeperkuat beberapa hasil penelitian. Hasil penelitian Pramono dan Setiawan (2019) menunjukkan bahwa anak-anak senang dan antusias memanfaatkan media berbasis augmented reality. Hal ini karena mereka lebih bisa cepat memhami dan mengerti konsep yang sedang dipelajari, karena tampilan media yang menarik dan lebih nyata. Selain itu, penelitian oleh Rusnandi dkk (2015) diperoleh data bahwa Augmented reality dapat dimanfaatkan sebagai media pembelajaran karena kemampuan pengolahan data secara cepat dan realtime, serta tampilan yang mudah dipahami oleh siswa SD serta bersifat interaktif dengan mode 3 Dimensi. Selain itu, media pembelajaran berbasis Augmented Reality mampu menciptakan suasana baru yang lebih interaktif dalam pembelajaran yang biasa terkesan monoton bagi siswa sekolah dasar.

Di sisi lain siswa sekolah dasar yang merupakan generasi alpha begitu akrab dengan gawai akan menggunakannya secara bijak. Selama ini siswa cenderung menggunakan smartphone untuk fungsi komunikasi dan hiburan saja. Dengan adanya buku berbasis augmented reality, mereka akan tahu bahwa gawai smartphone juga dapat digunakan untuk belajar. Dengan kata lain, siswa dapat menggunakan smartphone dengan bijak. Hal ini dapat disebut juga siswa menjadi manusia yang literat teknologi atau memiliki literasi teknologi.

\section{Pemanfaatan Bahan Bacaan Augmented Reality}

Pelaksanaan gerakan literasi sekolah selama ini berfokus pada pembiasaan membaca untuk melahirkan generasi literat. Pembiasaan yang dilakukan yaitu dengan membaca buku-buku yang telah dimiliki siswa sendiri ataupun buku milik sekolah. Buku-buku ini biasanya terdapat di pojok baca masing-masing kelas dan perpustakaan sekolah. Koleksi sekolah memiliki kecenderungan yang itu-itu saja. Idelanya koleksi sekolah memiliki buku-buku koleksi termutakhir dan terkini, sehingga siswa dapat lebih tertarik lagi pada kegiatan literasi.

Penggunaan variasi dalam kegiatan membaca juga dibutuhkan. Menurut Kemendikbud (2016) Pembiasaan membaca pada gerakan literasi sekolah idealnya menggunakan beragam alternatif strategi. Berpijak pada prinsip inilah guru sebagai pelaksana utama dapat mengembangkan kegiatan literasi disekolahnya. Guru juga berpeluang untuk menggunakan variasi bahan bacaan sebagai strategi bahan literasi.

Strategi alternatif yang digunakan oleh guru yaitu menggunakan buku bacaan yang berbasis augmented reality. Buku ini penggunaanya akan dibantu gawai smartphone maupun tablet pc. Oleh sebab itu, buku ini berpotensi untuk menjembatani siswa generasi alpha yang lebih akrab gawai mulai mengakraban diri juga dengan kegiatan membaca secara menarik. Langkah-langkah yang dapat dilakukan oleh guru untuk memanfaatkan buku bacaan berbasis augmented reality untuk gerakan literasi sekolah dasar yaitu sebagai berikut. 


\section{Pertama, Mempersiapkan bahan bacaan}

Guru mempersiapkan terlebih dahulu beragam alternatif bahan bacaan yang dapat digunakan sebagai bahal pembiasaan literasi. Buku-buku yang sudah berbasis augmented reality didata terlebih dahulu. Selanjutnya guru dapat memilah dan memilih buku-buku ditinjau dari segi kesesuaian dengan tingkat perkembangan siswa. Kemudian dilihat kepraktisan dalam pengoperasian buku bagi siswa apabila digunakan selama literasi di sekolah. Disisi lain dapat ditinjau juga dari segi kemenarikan buku bagi siswa.

\section{Kedua, memilih sumber bahan bacaan}

Buku-buku bacaan berbasis augmented reality yang telah dipilah dan dipilih oleh guru kemudian dibawa didalam kelas. Siswa diberi otonomi memilih buku yang ingin dibaca. Buku-buku yang dipilih diharapkan juga memiliki keterkaitan dengan tema pembelajaran yang dilaksanakan, sehingga memberikan pengayaan bagi siswa untuk pembelajaran.

Ketiga, menginstal aplikasi untuk buku berbasis augmented reality pada gawai

Siswa menginstal aplikasi augmented reality milik buku yang dipilihnya pada gawai yang dimilikinya masing-masing. Tahap penginstalan ini sebaiknya dibimbing dan diawasi oleh guru. Siswa menginstal aplikasi untuk pemindaian augmented reality sesuai langkah-langkah panduan dari buku yang dipilihnya.

\section{Keempat, Kegiatan membaca}

Pada kegiatan membaca siswa diminta membaca buku-buku yang dipilihnya. Apabila ingin menggunakan augmented reality, siswa diminta menjalankan aplikasi sesuai petunjuk umum pada buku yang mereka baca. Ketika siswa mengalami kesulitan, guru sesegera mungkin untuk membantunya. Pada kegiatan membaca ini dilaksanakan seinformal mungkin. Menjauhkan siswa dari rasa tertekan, namun juga membuat siswa senyaman mungkin menikmati bukubuku dengan animasi tiga dimensi melalu teknologi augmented reality ini. Suasana yang dibutuhkan yaitu santai dan menyenangkan. Hal ini mendorong siswa untuk gemar membaca.

\section{Kelima, Kegiatan diskusi}

Kegiatan terakhir yaitu melakukan diskusi informal. Diskusi berlangsung senyaman mungkin dan menyenangkan. Hal yang perlu diingat yaitu siswa tidak dituntut untuk nilai. Diskusi membahas tentang buku yang telah dibaca oleh masing-masing siswa. Diskusi dapat membahas tentang tokoh-tokoh dalam buku, amanat yang terkandung, hal-hal yang menarik terdapat dalam buku dan pengalaman selama menggunakan buku bacaan berbasis augmented reality. Umpan balik dari siswa melalui diskusi ini dibutuhkan oleh guru. Hasil diskusi ini dapat digunakan untuk perbaikan kegiatan kedepan yang berbasi augmented reality.

\section{KESIMPULAN}

Pemanfaatan sumber bacaan berbasis augmented reality untuk gerakan literasi di sekolah dasar ini bertujuan memberikan alternatif strategi pelaksanaan literasi. Kegiatan literasi diharapkan tidak berjalan membaca sumber buku-buku yang berjenis itu-itu saja. Berbagai potensi terkandung dalam pemanfaatan buku berbasis augmented reality. Buku dapat membantu guru supaya siswa meningkat 
kemauan untuk membacanya. Siswa sekolah dasar saat ini masuk pada generasi alpha yang merupakan pribumi teknologi. Sejak lahir mereka akrab dengan teknologi dan gawai itu sendiri. Buku berbasis augmented reality ini menjadi jembatan bagi siswa. Dimana siswa yang akarap dengan gawai juga diakrabkan dengan buku bacaan melalui teknlogi augmented reality. Oleh karena itu, buku sumber bacaan ini memiliki kemenarikan bagi siswa. Sebagai dampaknya siswa akan betah berliterasi dengan membaca.

Pada pelaksanaan literasi di sekolah dapat dilaksanakan melalui langkahlangkah sebagai berikut: (1) mempersiapkan bahan bacaan; (2) memilih bahan bacaan; (3) menginstal aplikasi untuk buku berbasis augmented reality pada gawai; (4) kegiatan membaca; dan (5) kegiatan diskusi. Pada akhirnya konsep pemanfaatan buku bacaan berbasis augmented reality ini diharapkan dapat diterapkan secara nyata dalam kegiatan literasi sekolah-sekolah di lapangan. Sebagai tindak lanjut diikuti juga dengan adanya penelitian yang mengkaji konsep ini.

\section{SARAN}

Kajian teoritis diatas terkait pemanfaatan Sumber Bacaan Berbasis Augmented Reality untuk Gerakan Literasi Di Sekolah Dasar masih sebatas kajian. Kajian ini perlu ditindaklanjuti dengan penelitain pengembangan maupun penelitian tindakan, agar Sumber Bacaan Berbasis Augmented Reality dapat dimanfaatkan dalam optimalisasi gerakan literasi di sekolah dasar. Kajian dan penelitian lebih lanjut dapat dilaksanakan secara kolaboratif antara dosen, guru, dan praktisi gerakan literasi di lapangan.

\section{DAFTAR RUJUKAN}

Azuma, R. 1997.A Survey of Augmented Reality. Presence: Teleoperators and Virtual Environments. 6 (4) p. 355-385.

Christina Sterbenz. 2015. Here's who comes after Generation $Z$ and they'll be the most transformative age group ever, (online), (https://www.businessinsider.com), diakses 1 September 2020

Toottel, Holle. 2014. Generation alpha at the intersection of technology, play and motivation, (online), (https://ro.uow.edu.au/eispapers/2068/), diakses 1 September 2020

Khotimah, K, Sadijah, C, Akbar, S. 2018. Pelaksanaan Gerakan Literasi Sekolah. Jurnal Pendidikan: Teori, Penelitian, dan Pengembangan. 3(11), 14881499.

Hidayat, M.H, Basuki, I.A, Akbar, S,. 2018. Gerakan Literasi di Sekolah Dasar. Jurnal Pendidikan: Teori, Penelitian, dan Pengembangan. 3(6), 810-816.

OECD. 2018. PISA 2018 Result, (online), (www.oecd.org), diakses 1 September 2020

Kemendikbud.2016. Panduan Gerkan Literasi Sekolah di Sekolah Dasar. Jakarta: Direktorat Jenderal Pendidikan Dasar dan Menengah Kementerian Pendidikan dan Kebudayaan Republik Indonesia.

Degeng, N.S. 2013. Ilmu Pembelajaran. Bandung: Kalam Hidup

Dahar, R.W. 2013. Teori Belajar dan Pembelajaran. Jakarta: Erlangga

Azuma, R.T. 1997. A Survey of Augmented Reality. 6(4), 355-385. 
Kesim, M., Ozarslan, Y. 2012. Augmented reality in education: current technologies and the potential for education. Procedia - Social and Behavioral Sciences 47. 297-302. mizanapps.com/augmented-reality.

Mustaqim, I. 2016. Pemanfaatan Augmented Reality Sebagai Media Pembelajaran. Jurnal Pendidikan Teknologi dan Kejuruan. 13 (2), p. 174 - 183).

Pramono, A. \& Setiawan, M. D. 2019. Pemanfaatan Augmented Reality Sebagai Media Pembelajaran Pengenalan Buah-Buahan. INTENSIF: Jurnal Ilmiah Penelitian dan Penerapan Teknologi Sistem Informasi. 3 (1), p. 54 - 68.

Rusnandi, E., Sujadi, H., \& Fauzyah, E. F. N. 2015. Implementasi Augmented Reality (AR) pada Pengembangan Media Pembelajaran Pemodelan Bangun Ruang 3D untuk Siswa Sekolah Dasar. Infotech Journal. 2 (1), p. 24 - 31.

Setiawan, H., Aji, S.M.W., \& Aziz, A. 2019. Puisi Berbasis Karya Gambar: Upaya Penguatan Literasi Siswa SD Kelas Tinggi. Inteligensi: Jurnal Ilmu Pendidikan, 2 (1), 50-60. (Retrieved from https://jurnal.unitri.ac.id/index.php/inteligensi/article/view/1559), , diakses 1 September 2020.

Setiawan, H., Aji, S.M.W., Aziz, A. 2020. Tiga Tantangan Guru Masa Depan Sekolah Dasar Inklusif. Briliant: Jurnal Riset dan Konseptual. 5 (2), DOI: http://dx.doi.org/10.28926/briliant.v5i2.458. (Diterima dari https://jurnal.unublitar.ac.id/index.php/briliant/article/view/458), diakses 1 September 2020.

Suryaningsih, Arifah. 2019. Gagasan Pengembangan Augmented Reality pada Buku Bacaan sebagai Upaya Meningkatkan Minat Baca Siswa (Adaptasi Percepatan Literasi dari Korea Selatan). Jurnal Ide Guru, 4 (1) Edisi Khusus Pelatihan Guru di Luar Negeri, (diakses dari https://jurnaldikpora.jogjaprov.go.id/index.php/jurnalideguru/issue/archive), diakses 1 September 2020.

Vallino, J. R. 1998. Interactive Augmented Reality. Rochester, New York: University of Rochester. 